\title{
人格同一性論と責任㷌属
}

一Parfitを中心に一

\section{On Parfit's View of Personal Identity and its Limitations}

\section{常松淳 \\ TSUNEMATSU JUn}

We all make judgements about personal identity in daily life and attach importance to it. In studying the question of personal identity, we are trying to clarify and analyze the concepts we have and the principles we employ in making such judgements. The empiricist theory of personal identity proposed by Derek Parfit has been highly influential. In this paper, I attempt to make a detailed explication of his theory and to review it from a sociological standpoint. I suggest that Parfit's theory of personal identity fails to illuminate the meaning of ascription of responsibility.

\section{1. 初めに}

ある人物とある人物が同じ人物であるとはどういうことなのか、一体どのような条件が 揃っていれば同一人物であると言えるのかといった問題、即ち人格同一性personal identity に関わる諸問題が、社会的世界における我々の認識と実践を理解する上で重要な意味を持 っていることは疑いない。そもそも「人格person」は社会的世界の一部を構成する主要な 存在であり、その同一性は、モノの同一性とは異なった独特の意味と役割を担っていると 考えられるからである。人格の同一性はしばしば、道德的な実践にとって極めて重要な前 提的基礎として扱われる。例えばThomas Reidは、人格の同一性が曖昧さを持たないこ と、それが程度の差を許すものではないことを指摘した上で、「それはあらゆる権利と義 務、そしてすべての責任accountablenessの基礎である」（Reid [1785]1975a: 112）と述べて いる(1)。責任帰属という面に限って言うならば、このような主張の背後には、責任とは、 問題となった行為の行為者であった人格と同じ人格にこそ帰属されなければならないとい う直観的な判断が存在すると言えるだろう(2)。

本稿では、人格同一性に関して提唱されている有力な理論、即ちDerek Parfitを現代に おける筆頭とする経験主義的(3)な人格同一性論を取り上げ、社会学的観点、とりわけ責任 帰属という文脈からの再検討を試みる。何故そのような観点からの吟味が必要かと言えば、 人格やその同一性といった問題は、それが実践的に問題化される責任帰属のような場面と 切り離して捉えることは出来ないと考えるからである。

\section{2. 人格同一性をどのように捉えるか}

(1)〈私〉の同一性と人格の同一性

さて、1では本稿の関心を「人格同一性に関わる問題」として描いたわけだが、問題を このような形で立てようとする場合に見過ごされがちな区別がある。本論に入る前に、ま すここの点に注意しておきたい。 
「今日の私が明日の私と、あるいは昨日の私と同一である必要十分条件は何か？」とい う問題に関して永井均は、そこで言及されている“私”には二つの解釈があり得ることを 指摘している。即ち、誰にでも取り替え可能な任意の私の同一性（永井の語法では、「私」 の同一性）と、世界に唯ひとりしかいないこの私の同一性（同じく、〈私〉の同一性）の 二つである（永井 1991：177ff.）。永井によれば前者の問題は、任意の人格についての同 一性問題が当人の内側から把握されたケースである。つまり、任意の「私」に関する同一 性の問題は人格同一性問題の一特殊ケースであり、世界がそこから開けている唯一の原点 としての〈私〉の同一性問題とは次元が異なるということである(4)。

「人格の同一性」として問題を考えるとき、そこでは対他的な視点が自ずから想定され ている。対象化された人格（そこには一つの人格としての自分自身も含まれるだろう）に ついてその同一性条件を考えるというスタンスである。永井が同書で指摘するように、こ れから論じる経験主義的人格同一性論は、「私」の人格も含めて、あらゆる人格を対象と して捉えることから始まっている(5)。そこではどのような問題の定式化が採用されている のかを次に見ておこう。

\section{（2）人格の同一性という問題}

さて、人格同一性の問題として考えられているのは、多くの場合「異なった文脈、記述、 時間における個体の再同定」に関わる規準である(6)。それは、ごく単純化して言えば、し ばしば次のような形で定式化される。

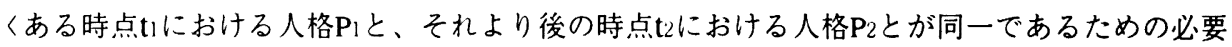
十分条件は何であるか?〉

このように通時的な同一性に焦点が絞られることは、ある意味で当然のことである。と いうのは、人格の再同定が同一の時点における複数の人格に関して為されるということは 考え難いからである。言い換えれば、同時に存在する複数の人格について、それらの同一 性が問われるということは、ほぼあり得ない（同時に別個に存在するものを同一と見なす ことはない）(7)。即ち、通時的な人格同一性において問われているのは数的同一性であっ て、質的同一性ではない(8)。こうして問題はむしろ、時間を隔てた人格の間で質的な同一 性（同質性）が成立していないにもかかわらず、数的な同一性が成立するのはどのような 場合かという意味をもつことになる。

上の定式化はまた、次のように変形されることも多い。

くある時点 $\mathrm{t}$ における $\mathrm{p} 1$ と、別の時点 $\mathrm{t} 2$ における $\mathrm{p} 2$ とが、同一の人格Pに属しているのはどのよ うな場合であるか?〉

p1やp 2 に、人格Pに属する「総体的な時間状態」（Grice 1941）、「人格ステージ」 (Lewis 1976）(9)などと呼ばれるものが代入される。これらは、ある人格に属する経験的 な状態を時間によって切り取った断面のようなもののことである。そのような時間切片 time-slice化された諸状態が同一の人格に属しているものであるときに、それら諸状態・諸 
ステージの間に成り立つ関係はどのようなものか、と問われるわけである(10)。逆に言え ば、人格とは、そのような諸状態が何らかの関係によって結びつけられた場合に現出する ものとして捉えられている。人格同一性がこのような経験主義的定式化の下に議論される 場合、Lockeに始まる（とされることの多い）、いわゆる「人格同一性の記憶説」が下敷き として存在している。それゆえ、上で言う「経験的な諸状態間に成り立つ関係」とは、主 として記憶のような心理的関係のことを指している(11)。

以上のように問題が定式化されるとき、人格について前提されている考え方は次のよう なものだ。つまりここにおいて人格とは、それに属する「状態・ステージ」が共時的・通 時的に統一関係に類した仕方で結びついたときに存立するようなものである。通時的な人 格の同一性は、諸状態間において、ある種の関係が成立するかどうかという経験的な事実 にかかっている。一定の経験的事実が成立していることが、時間を貫くような人格を構成 しているという認識である。人格とその同一性についての議論を、それ自体で成立してい る自然的（経験的）事実に還元するという経験主義的な図式は、Parfitにおいて更に徹底 され、展開されている。そこで、次にそのParfitの人格同一性論の内実を明らかにしてお きたい。

\section{Parfitの人格同一性論}

\section{(1) 改訂主義}

Parfitの議論を扱う際に留意しておかなくてはならないのは、彼のスタンスである。即 ち彼は、本人が認める通り（Parfit $1984=1998:$ IV) 改訂主義者revisionistである。彼は単 にわれわれの実践を記述するだけでは満足しない。本性についての真なる像を描き出した 後、彼はわれわれの常識的な信念が誤っている（ないし不斉合に陥っている）ことを指摘 し、それをどのように改訂すべきかを示唆する。彼の主眼は、信念と実践の改訂を通じた 「合理性」の探求である。人格に関わる問題で言うなら、彼の論点は大きく分けて二つあ る。一つは、人格とその同一性がどのようなものであるかに関してわれわれが直観的に抱 いている信念は誤っている（ないし不斉合に陥っている）ということであり、もう一つは、 その信念の下でわれわれが人格同一性に与えている重要性は、人格同一性の本性について の新たな（正しい）理解に照らして減じられるべきだということである。彼は、合理性、 道徳的判断、感情といったものが事実についての正しい認識に基づくものであることを求 めているのである（Parfit 1995: 33）。

彼の議論は基本的に以下のような手順を踏む。まずParfitは、実際上は起こり難いよう なケース（情報の転送によってレプリカを作製することを通じた火星への遠隔輸送・脳を 半球ずつ二つの身体に移植する大脳分割移植・ある人と全くの別人との間を、ほんの僅か ずつだけ異なった無数の人格によって埋めて出来上がる心理-物理的スペクトラム）を想 像してみるようわれわれに要請する。そして、それらのケースに対するわれわれの直観的 な反応の仕方から、われわれが暗黙のうちに抱いている人格同一性についての信念を摘出 し、それに根拠がないことを示そうとする。そして、人格同一性を構成している事実につ いての正しい認識の下で何が重要視されるべきかを論じ、その認識の下でどのような道徳 的信念や合理性の基準（Parfitの最大のターゲットは合理性についての自己利益説である） が「もっともらしいplausible」ものであるかを比較検討するわけである。Parfitはこう主張 
する。

「想像上のケースを考察するときにわれわれの信念は最もはっきりと明らかにされるが、これ らの信念は現実のケースも、またわれわれ自身の生livesもカバーしている。」(Parfit 1984=1998: 281)

果たして人格やその同一性に関わる我々の概念やそれについての判断は、上のような方 法によって汲み尽くされるものであろうか。以下では、まず人格（とその同一性）につい てParfitが何を主張しているかを点検した後、この問題に立ち返りたい。

\section{（2）〈還元主義〉が否定するもの}

Parfitは人格同一性の本性、つまり何が人格の同一性を構成しているのかに関する二つ の対立する見解を対照させながら議論を進める。Parfitの採る立場がく還元主義 Reductionism〉、対照される考え方が〈非-還元主義Non-Reductionism〉と呼ばれている。 Parfitによれば、われわれが直観的に抱いているのがく非-還元主義〉の方であり、この 〈非-還元主義〉的見解には実は根拠が無く、〈還元主義〉こそ採られるべき見解だと彼は 主張する。Parfitはある䇢所で「重要なのはこの [〈還元主義的〉：引用者］見解が主張す ることよりもむしろ、それが何を否定するかにある」と言っている（Parfit 1986: 291）。 では、〈還元主義〉によって何が否定されているのかを先に見てみよう。

〈還元主義〉が否定するのは、もちろん、〈非-還元主義〉である。さて、我々が暗黙の 内に抱いているとParfitが主張する〈非-還元主義〉的な見解とはどういうものか。Parfitに よれば、われわれは「人格同一性についての問題には、必ずYesかNoの答えがある。将来 において生じる経験は、私の経験であるか、そうではないかのいずれかである（即ち、そ の答えは確定したものである)」と信じている。そしてこのように信じているとき、われ われは〈非-還元主義者〉に分類される。そしてある種の〈非-還元主義者〉としてのわれ われが「人格の同一性は確定したものであって、単純にあるか無いかのいずれかである」 と信じるためには、霊魂やデカルト的自我Cartesian Egoといった非物質的な実体の存在を 信じていなくてはならない筈だとParfitは論じ進める。例えば大脳分割移植（脳の半分を 今の身体と類似した二つの身体にそれぞれ移植するケース。このとき、脳は半分だけでも 従来と同じ機能を果たすことが出来ると仮定される）のようなケースで、術後に存在する 二人のうちどちらが術前の人格と同一かについて確定した答えがあると考えるならば、わ れわれは〈非-還元主義〉に立っていることになる。というのは、そのような「非物質的」 実体が存在していると信じない限り、パズルケースにおいて人格同一性の確定的な答えが あると想定することは出来ないからだとParfitは言う(12)。

そして〈還元主義〉は、非物質的な〈デカルト主義的自我〉のような存在を否定する。 ただその論拠はアプリオリなものではない。Parfitは、〈非-還元主義〉が真でもあり得た可 能性を信じていると述べている。ただ、実際にはその存在を支持するような経験的な証拠 が見出されていないが故に否定されるべきだと主張しているのである（Parfit 1984，§ 82)。つまり、Parfitは経験的根拠によって〈非-還元主義〉を否定する。

〈還元主義〉が何を否定しないのかにも触れておかなくてはならないだろう。まず、 
〈還元主義〉は、人格が時を通じて同一であるという事態そのものが不可能だと言ってい るのではない。通常のケースにおいて人格の同一性が成立するものであることは認められ ているのであって、そこに事実として何が含まれているかという点を巡って〈還元主義〉 と〈非-還元主義〉は対立している（〈還元主義〉の考える人格同一性については後述）。 つまり同一性という関係が存在するかどうかが争われているのではない。また、しばしば 誤解されるように、人格同一性が程度問題だと主張されているわけでもない。同一性とい う関係がall or nothingであることは動かされない。そうではなく、人格同一性において 〈重要なこと〉(後述) は程度を持っているという点が強調されるのである(13)。

\section{（3）〈還元主義〉が捉える人格同一性の本性}

次に、〈還元主義〉は人格についてどのような主張をするのかを見てみよう。〈還元主義〉 によれば、時間を通じた人格の同一性が含んでいるのは、物理的・心理的継続性のみであ って、それ以上の事実はそこには含まれない。通常のケースのように時間を通じた同一性 が成り立つのは、〈R-関係〉を持った他の人格が存在しないという（言い換えれば、〈R-関 係〉が“分岐しない”という）条件においてである。ここで〈R-関係〉とは、心理的連結 性connectedness及び/あるいは心理的継続性continuityを指す。心理的連結性とは、記憶や、 意図・欲求etc.の持続のような、異なる心的状態の間に成り立つ関係のことであり、心理 的継続性とは、強い連結性のオーヴァーラップする連鎖のあることである。

遠隔転送装置のケースや脳分割移植のケースでは、元の人格と、一定の操作後に現れた 複数の人格との間には〈R-関係〉が成り立っている。というより、この想像上のケースで は、通常に生存していくケースと全く同じだけの〈R-関係〉を保存するような仕方で人格 の数が増やされているのである。Parfitによれば、通常のケースでは〈R-関係〉の継続性 と同一性は一致coincideしているが、それは〈非-還元主義〉が想定するような「個別的に 存在する実体」としての人格が保証しているからなのではない。にも拘わらず、想像上の ケースについてなお「生き残った人格のうち、どちらが私なのか？」と問うならば、それ は空虚なempty問いだとされる。Parfitがそれを空虚だというのは、心理的・物理的継続性 に関する事実を既に知っているならば、われわれは全ての事実（何が起こったか）を知っ ているのであって、その時「われわれは同一性についての疑問を、単に言語についての疑 問に過ぎないものと見なすべき」(Parfit 1995: 24）だという意味においてである。

以上の説明から明らかなように、Parfit的〈還元主義〉にとって、人格の通時的な存在 に関する現実realityと呼べるのは心理的・物理的継続性という、いわば自然的に成立して いる経験的事実のみである。ここでは徹底して経験主義的な事実観が採られており、「ど ちらが私なのか?」のような問いは単に「概念的な問題」「言葉の問題」に過ぎないもの とされてしまう。「どちらが私なのか?」と問うよりも、「どちらを私と呼べばよいか」と 問うべきだとParfitは言う。彼によれば、前者の問いに対して、法的な目的のために答え を与えるよう場合があるかもしれないが、それは問題に答えたわけではなく、ただそう決 定したのに過ぎない（Parfit 1995: 26)。

このように、Parfitが捉えた「時間を通じて存続する人格」は、人がそれをどのような ものと考えるかとはひとまず無関係に成立している事実によってのみ構成される。人が人 格を巡って抱く様々な信念は、むしろ、この事実を中心に置いた立場から評定されること 
になっているのである。

Parfitは分裂ケースをもとに、次のようにも論じている。脳の半分が破壊され、残りの 半分が成功裏に移植されて活動を再開するなら、もとの人格が生き続けるということは直 観的に明らかだが、もしそうであるなら、脳の半分をそれぞれ別の（しかし似通った）身 体に移植して生じた二つの人格と元の人格との間で、内在的な性質において欠けているも のは何一つないと言わなくてはならない。通常の生き残りとまったく同様の〈R-関係〉が 保存されているからである。即ち、ここに根本的に重要なこと what mattersは含まれている。

人格の同一性という事実は、R-関係が非分岐的形態をとっているときに、その関係が成立して いるという事実だけからなっている。もし人格の同一性がこのR-関係だけからなっているならば、 後者の関係こそ重要なものに違いない。(Parfit 1984=1998: 362)

Parfitの考えでは、重要なのは内在的な性質、つまり〈R-関係〉の方であって、分裂ケ 一スにおいて同一性が成立しないのは大したことではないのである(14)。Parfitにとって 〈R-関係〉に関する事実だけが、人格についての唯一のリアリティであり、「重要なことは 現実realityであって、それがどのように記述されるかではない」(Parfit 1995: 32)。人格同 一性の場合その重要な事実とは、〈R-関係〉の継続性に尽きるのである(15)。

*

本章冒頭で触れたように、本性をなす事実こそが道德や合理性に関する判断にとって重 要なものだというのがParfitの立論である。そこで彼の次なる課題は、〈還元主義〉が真で あるとするなら、どのような態度や判断が正当化されるか、という規範的なものとなる。 この問題は、もし〈還元主義〉を受け入れたなら、事実としてわれわれはどのような態度 をとるだろうか、という問題とは区別されなくてはならない。本稿の関心は、Parfitの規 範的主張の当否ではなく、彼の人格同一性論が我々の概念的実践をどこまで捉え切れてい るかという点にある。そこで次に、人格の同一性が実際に問われる文脈に即してこの問題 を考察してみたい。本稿で取り上げるのは責任帰属という文脈である。ある意味で、これ は人格の同一性という問題が極めて先鋭的に関わってくる場面だと思われるからである。 逆に言えば、このような実践的場面においてこそ人格同一性は主題化されるのだと言えよ う。人格やその同一性といった概念が実践的に用いられ機能する文脈の中で、Parfitの人 格同一性論を再検討してみる。

\section{4. 責任帰属と人格同一性論}

（1）〈還元主義〉の責任論

Parfitはその〈還元主義〉的人格同一性論を下敷きにして、責任帰属のような実践をど のように捉えているか、まずこの点から明らかにしていこう。道徳的判断についての検討 を行うにあたっても、彼は〈還元主義〉と〈非-還元主義〉とを対比させる方法を使う (Parfit 1984=98: 445-8) (16)。

責任帰属との関連で取り上げられるのは、

《もし〈還元主義〉が真であるなら、われわれは自分の犯した犯罪のために処罰される ことはあり得ない》 
という見解、即ちParfitが呼ぶところの〈極端な主張〉である。〈非-還元主義〉は、たとえ デカルト的自我のような実体を認めないとしても、それでも人格の同一性は心理的・物理 的継続性という事実には還元されない「更なる事実further fact」を含んでいると主張する かもしれない。そして、仮にそのような〈更なる事実〉だけが功績や責任を伴うと想定さ れるならば、〈極端な主張〉が採られていることになる。というのは、〈R-関係〉のみを事 実とする〈還元主義〉は〈更なる事実〉の存在を否定するからである。

ところが、Parfitは単純にこの主張を採用するわけではない。く極端な主張〉が依拠する この想定と、心理的継続性は功績を伴うという主張は両方とも弁護できるものであり、そ の不一致を決定的に解決する議論をまだ発見していないとParfitは言うのである（Parfit 1984=1998: 447)。つまり彼は、功績や責任が〈更なる事実〉を要するのか、それとも心 理的継続性だけで十分であるのか、決定的なことは言えないと言葉を濁す(17)。

ただParfitは、〈還元主義〉の立場から積極的な主張も行っている。それは、連結性は程 度を持つという〈還元主義〉の見解から導かれるもので、「ある囚人とその犯行時の彼自 身との連結が薄くなれば、彼はそれだけ処罰に值しなくなる」というものである （Parfit1984=1998: 447）。つまり責任の程度は連結性の程度に対応するという主張である。

この主張には吟味が必要だろう。まず一見したところ、これはわれわれの直観とある程 度一致しているように思われる。しかし、「連結性の低下」のみによって必ず免責される とは限らないということもまた、我々の直観に含まれている。それはこういうことである。 連結性の低下に伴う責任の減免を主張するためにParfitが与えている具体例（90歳のノー ベル平和賞受賞者が20歳の時に警官を傷つけていた場合）のように、性格特性が言わば “良い方に”(より精確に言うなら、もはや再び警官を傷つけたりしないような方向へと） 変化するという意味での連結性の低下が生じることは現実に起こりうるであろう。しかし 他方、例えば単に忘れてしまっただけでは、連結性は低下しこそすれ、(Parfit自身が指摘 するように(18)) 責任が減じられるとは限らない。では昔の犯罪を強く反省している者は どうか。彼は過去の出来事をむしろ強烈に記憶し続け、常に自分を責め、悔いる毎日かも しれない。この意味での連結性は低下していないが、彼の責任が減じられる可能性は、無 反省なまま性格の変わってしまった人よりも高いのではないか。このように、連結性の程 度と責任の程度を単純に対応させることが出来ないのは、彼の何について責任を問うのか という点が関わってくるからである。

別の例で考えてみよう。Parfitがしばしば思考実験として導入するレプリカのケースが ある。複製される以前に原初人格が犯した犯罪の故に、そのレプリカを罰することが出来 るかという問いに対してわれわれは、「いくら継続性があっても、彼は原初人格その人で はないが故にNo」と答えるだろうとParfitは言う（Parfit 1986: 296）。そして彼によれば、 そのような直観的応答によって次のこと、即ち、責任帰属には単なる〈R-関係〉以上のも のが必要であり、そのような〈更なる事実〉が存在すると我々が信じているということ (《還元主義〉者ではないこと）が示されている、ということになる。レプリカに責任はな いと考えることの中に、もとの人格にはあるがレプリカには欠けている何かが存在すると 信じていることが含まれている、ということである。

確かに、レプリカが例えば「私がやったことじゃない。彼（＝原初人格）がやったこと だ」と言い張れば、われわれは責任䯋属を躊躇してしまうかもしれない。しかし、Parfit 
が無前提に想定する如くこれが唯一の直観的な反応とは限らない。〈R-関係〉が保存され ているレプリカは少なくとも「そんなことをした覚えはない」と（誠実に）言うことはで きないのであり、また仮に「私がやったことじゃない」と言えるとすれば、それは彼が自 分はレプリカであると知っている場合に限られる。Parfitは、問題はレプリカが真実を知 っている場合に彼が何を正当に主張できるかということにあると述べている（Parfit 1986, n.16)。しかし、〈R-関係〉が丸ごと保存されているレプリカは、仮に原初人格が罪を認め 反省しているような人物である場合、そもそも「自分は罰せられるべきでない」と主張す るであろうか。更に言えば、もしそのレプリカが被害者に向かって「ざまあ見ろ」と言っ たならどうであろうか。彼がレプリカであるという理由だけで、われわれは責任帰属をた めらうだろうか。

ここでわれわれが問いたい問題は、実際にどちらの直観が抱かれるかということではな い。それは人によって異なるであろうし、なおかつ、一人の人が相反した直観を同時に抱 くということも分ありうるだろう。本稿の関心は、これらの直観の違いは、われわれが 責任帰属をどのような角度から捉えているかの違いと連動しているのではないかという点 にある。次にこれを明確にしたい。

\section{（2）行為責任と性格責任}

責任を帰属するとき、いったい何について責任を判断するのか、つまり責任判断の対象 をどこに求めるかによって、責任の種類を大きく二つに分けることが出来る(19)。責任判 断の対象を問題となる行為のみに求める場合、そのとき問われている責任を行為責任と呼 ぶ。一方、責任判断の対象を行為者の性格に求める場合、これを性格責任と呼ぶ。このと き、問題の行為に直接繋がるような行為者の性格だけを対象として取り出すのか、それと も、その行為者の性格全体を判断の対象に含めるかによって責任帰属のあり方は異なるも のとなる。即ち、対象となる性格の範囲をどれだけ広げるかによって責任判断は大きく変 わってくるのである。問題となっている行為を引き起こしたことと直接的に結びついては いないような性格までをも責任判断において重視すればするほど、性格責任論は行為責任 論から離れていくことになるだろう（森村 1987: 61）。そして行為責任から離れる程に、 それは道德的責任からいわゆる「社会的責任」に近づいていく。ここでは、あくまで何ら かの行為を巡って下される責任帰属のあり方に焦点を絞っているが故に、社会的責任は考 察から除外しておく。

さて、責任帰属におけるこの二つの観点は、互いに両立しないものではなく、実践的に はむしろ常に同居しているものである。前節の例にあったように、被害者に向かって酷い 言動をとったレプリカに責任を帰属したくなるとき、われわれは性格責任論的な観点を採 っていると言える。レプリカが現に持つ、犯行と直結しているような性格を責任判断の対 象に含めていると考えられるからである。「責任があること」を非難可能性と読み替える ならば(20)、レプリカの（犯行に直結した限りでの）性格を非難しているのである。ただ し、この例で同時に行為責任をも帰属しているのかどうかは一概に言えない。く極端な主 張〉が含んでいた想定（＝原初人格は持っているがレプリカには欠けている何かがあり、 それ無しでは責任は問えないという想定）が貫徹されるならば、レプリカに行為責任は無 いと結論されるであろうし、そもそも、行為責任がレプリカより先にまず帰属されるであ 
ろう原初人格が存在しているからである。

既に述べたように、年老いたノーベル平和賞受賞者は遠い過去の犯罪のために処罰され るには值しないと主張していることから分かるように、このときParfitは性格責任的観点 に傾いている。犯罪を犯す原因となったような性格特性を今は失っているが故にその老人 は免責されるべきだというのであれば、そこで責任判断の対象は部分的には現在の性格に 求められているからである。

一方、行為責任的観点について、Parfitは次のような趣旨のことを述べている：「それ でもそれは彼の犯罪であったことに変わりない」という主張（以下 $\mathrm{P}$ と呼ぶ）は確かに真 理ではあるが、その真理は〈還元主義者〉にとって重要ではなく、責任の減少という主張 を論駁出来ない、と（Parfit 1984=1998：448）。ここでPの含意するところを見極めるた めには、責任の有無と責任の程度を区別しなくてはならない。字義的にはP $\mathrm{P}$ は、通時的に 継続してきている彼の人格に犯罪行為を帰属しているに過ぎない(〈還元主義〉のターム を使えば、犯罪を起こした状態と今の状態とは、分岐しない〈R-関係〉によって結ばれて いるという主張）のだが、同時に、その事実によって今の彼にも責任があると示唆してい る。しかしPは、責任の程度には明示的には言及していないので、Parfitの主張と対立し てはいない。Parfitは今の彼に、程度はどうあれ責任があることは認めているからである。 この点からして、犯罪行為を犯したときの彼と今の彼との間に〈R-関係〉の継続性がある ことは、Parfitにとって全く意味を失っている訳ではないはずである。しかし、もし Pに 「責任の程度は行為の性質のみによって決まり(21)、それは時を経ることによって変化しな い」という想定が加わるならば、Parfitの責任低減説と衝突するだろう。

このように、人格同一性についての見解のみから責任帰属に関する唯一の見解が導かれ るわけではない。何について責任を問うのか、責任の程度を決める規準はどこに求められ るかという問題と切り離せないからである。

\section{5.人格同一性の意義}

性格責任ではなく行為責任のみを問うとき、われわれは行為のみを責任判断の対象にす ることになる。注意しなくてはならないのは、行為は責任判断の対象であるという点であ る。ある行為に対する単なる否定的評価を越えて責任を問う場合、われわれは出来事とし ての行為そのものを非難したり、行為そのものに責任を帰属するということは出来ない。 実践的には、ある行為について誰かを非難し、誰かの責任を問うという形式をとって、行 為の帰属先としての「人格」を責任の引き受け手として要請している。

では、そもそも、行為責任の帰属と心理的・物理的継続性との関係はどのように考えら れるべきなのであろうか。Parfitには、〈R-関係〉の継続性だけで行為責任を問うには十分 だと考える選択肢（つまり、通常のケースにおいては〈非-還元主義者〉と同様の責任判 断に落ち着き、分岐線ケースのレプリカにも同程度の責任があると考える選択肢）が論理 的には残されている。しかし、配分的正義を論じる際（Parfit 1984，§111-115；1986）に 典型的に表れているような、人のその時々の経験や状態をより重視する志向からして、 Parfitがそれを採ることはないであろう(22)。ただ一方で、Shoemaker（1985）が指摘するよ うに、もし〈非-還元主義〉が真であるとしたなら、なぜ人格の同一性が重要なものであ り、なぜ道徳的功績やコミットメント、配分的原理がより問題なく適用できるのかについ 
て、「それが〈更なる事実〉を含んでいるから」ということ以外、Parfitは論じることが出 来ていないのである。

ここで本稿が指摘したいのは次の点である。人格やその同一性に関する我々の考え方は、 明らかに、レプリカというものが存在しないような社会的条件の下で積み上げられてきた 実践の中で形作られている。レプリカの存在が当たり前ではないような世界において、わ れわれは多様な具体的場面で人格の同一性を判定したり、それに基づいて何らかの道德的 判断を下したりしてきたのである。それゆえ、「果たしてレプリカに責任はあるか？」と 問う思考実験の意味は、この問いを取り巻く状況としてどのような世界を想定するかとい うことに大きく依存している。その問いは、この世界、即ちレプリカというものがほほ想 像上の産物であるようなこの世界に突如として生じたレプリカについてのものなのか。そ してその時、レプリカはどのような意図で作られたかと想定されているのか？あるいは、 そもそもこの問いは、レプリカの生成が常態であるような世界に生まれたレプリカについ てのものなのか。この違いは重大である。というのは、人が定期的に分裂するような状態 が連綿と続いてきたであろう後者のような世界では、人格やその同一性の捉え方やその意 味が、われわれとは本質的に異なっているかもしれないからである(23)。Parfitの議論では、 二つの世界が曖昧に折衷されてしまっている。どちらの世界においても、レプリカと原初 人格との間で、Parfitの重視する〈R-関係〉は保たれている。しかし、その実践上の意味 づけが同じであるはずだと想定できる理由は見当たらないのである。

われわれの直観はある意味で、必ずしもレプリカの責任を認めないものではないと上で 論じた。これに対してParfitならば次のように応答するだろう。「どちらの世界においても、 仮にレプリカに性格責任的な意味での責任を認めるとしても、行為責任を認めることは無 いであろう」と。確かに言われる通りかもしれない。しかし、Parfitの予想に“もっとも らしさ”が見出されるとしてもそれは、われわれがく更なる事実〉を信じているく非-還 元主義〉者であるからというより、人が増殖するような世界で、現在われわれが抱いてい るような行為責任という観念が生き延び得るかが疑われているからだと言うべきである。 このように、私の考えでは、経験主義的なアプローチを採る人格同一性論は、人格同一性 が何に存するかという問いかけから出発し、そこのみを考察の起点としているために、社 会的実践において人格同一性が担っている意味を解明することが出来なくなっているので ある。

註

(1) 他に盛山（1995: 277）参照。

(2) 行為者ではない者の責任を問う教唆や幇助といった責任帰属のあり方は別の事柄である。

また、責任帰属についての判断において採られる原理が歴史性を帯びていることは言うまでもない。 しかし本稿の課題は、歴史的な变遷を記述すること（例えば作田（1972；Ｉ「責任の進化」）はこれを 行っている）にあるのではなく、人格同一性論と責任帰属との関係を問い直すことにある。以下の議 論において引き合いに出される諸々の “直観”は、当然のことながら、歴史的な制約を受けているは ずである。

(3)「経験主義的empiricist」という用語はSwinburne（1984）から借りた。

(4) これら二つの視点の解離が社会的にどのように処理されているか、という問題は探求されるべき重 要な論点である。以下での本稿の議論も、この観点から再検討される必要があろう。 
（5）これと対応して、以下でなされる検討は、他者に対して責任を帰属するという文脈に限定されてい る。自己に対する責任帰属のあり方は、また別個の解明を要するだろう。

(6)「人格」という概念をどのように問うかについての整理として、Rorty（1976b）を参照。

(7) 一方、ある時点において「そこには幾つの人格があるか」ということが問題化するケースがありう る。野矢茂樹は、行為者の数という観点からこの問題を論じている (野矢 1999: 27章)。

(8) 私が持っているパソコンと性能・形・色の面で全く「同じ」パソコンを持っている人は大勢いる。 しかし、誰か他のひとの所有しているパソコンは、私のパソコンそのものではない。前者の意味の同 一性を「質的同一性qualitative identity」といい、後者を「数的同一性numerical identity」という。他 人のパソコンと私のそれは（初期状態では）質の面において殆ど同じである。つまり質的同一性は成 立している。しかし、それらは数的に同一であるわけではない。それらは異なる二つのパソコンだか らである。

(9) 他にPerry（1975b, 1976）も同梯である。

(10) Perry（1975b）はこの関係を「統一関係unity relation」と呼んでいる。数的同一性と異なり、この 関係は共時的にも成り立つものである。

(11) 一ノ瀬正樹（1997: 133-4）は、Lockeにしばしば帰せられ、しかも一見対立しているように見える 人格の意識説と法廷用語説を、むしろ後者の側に引きつけて統一的に理解べきだと主張しており、人 格同一性についても経験主義的描像に対して批判的である。

(12) ただParfitは、われわれが実際にデカルト的自我の存在を信じていると主張したいわけはないとも 言う。つまり、彼にとっての問題は、われわれの信念が不整合に陥っているという点にあることにな る (Parfit 1995: 27-8)。

(13) もう一点、〈還元主義〉が否定しないのは、実体entityとしての人格の存在である。この点はやや分 かりにくい。Parfitは「個別的に存在する実体separately existing entity」としてのデカルト的自我のよ うな人格は否定するが、脳・身体・思考・経験・意識状態とは区別されるdistinct人格という実体は認 めると言う。ここで区別の基準はその存在様態に求められている。脳・身体etc.から区別される実体 としての人格の存在は、脳・身体etc.の存在のみに存する、という点において「個別的に存在する」 のではないというのがParfitのポイントであるようだ（Parfit 1984=1998: 637-8）。

(14）分裂ケースにおいて失われてしまうものは存在する。その人格の唯一性である。Susan Wolf (1986) は、人格の増殖は実際上の様々な問題（例えば、增殖後に財産をどう処分するか）を産み出すが故に、 同一性よりも〈R-関係〉を重視することは出来ないとParfitを批判している。これに対するParfitの反 論は（Parfit 1984=1998: 363-5）を見よ。

後に触れる論点を先取りすることになるが、人格の增殖がどのような実際的問題を引き起こすか は、社会的状況に依存するのであるから、それを抜きにして重要性の多塞を考えることに意味はな い。

(15) Mark Johnston（1997）は、重要性は還元される前の事実にこそ見出されるべきだと批判している。

(16) ただ、責任を含めた「功績desert」についてのParfitの主張は明断なものとは言い難い。Parfitの議論 は、こと人格同一性や道徳的判断の問題に関する限り、“もっともらしさ plausibility”の主張にとどま るもので、決定的decisiveなものは目指されていないからでもあろう。Parfit（1986: 295）参照。

(17) 森村進は、『理由と人格」においては〈極端な主張〉を否定していたParfitが (邦訳476頁参照)、後 には、人は過去の行為については責任を負わないという説を積極的に主張していると述べている（森 村 1989: 121)。しかし私見では、Parfitは、（Parfit 1986）においても、「もしレプリカに責任がない と見なすならば、もとの人格を含めて処罰に価する人は誰もいないことになる」という条件文を主張 するにとどまっている。

(18) Parfit $(1984=1998: 447)$ 。

(19）森村（1987）参照。ただし森村じしんは、より細かい分類を提示している。

(20) もちろんこのような読み替えが常に適切なわけではない。「責任はあるが非難は出来ない」という 事態が考えられるからである。 
(21) 刑法論においては、これが行為責任論的立場からの量刑基準である。森村によれば、量刑の規準に 関して行為責任論を貫徹している論者は殆どいないという（森村 1987: 79）。

（22）非人格的な功利主義への傾きを考えるなら、Parfitが更に「社会的責任論」へと赴いても、驚くに は価しないかもしれない。

(23) 人格同一性論においてしばしば用いられる「身体交換の思考実験」についても同様である。永井均 はこの点を捕らえ、ある人物が誰であるか（「私」の同一性）に関する判断において「決定的に重要 な意味をもつことになるのは、その判断がなされる社会で一般に受け入れられている世界像である」 （永井 1991：180）と述べている。

\section{文献}

Dancy, Jonathan ed., 1997, Reading Parfit, Blackwell.

Grice, H. P., 1941, "Personal Identity", Mind, 50. Reprinted in Perry (1975a)

一ノ瀬正樹、1997、『人格知識論の生成—ジョン・ロックの瞬間』東京大学出版会.

Johnston, Mark, 1997, "Human Concerns without Superlative Selves", in Dancy (1997).

Lewis, David, 1976, "Survival and Identity", in Rorty (1976a).

森村進、1987、「行為責任・性格責任・人格形成責任」『法の理論 8』成文堂.

1989、『権利と人格』創文社.

永井均、1991、『〈魂〉に対する態度』勁草書房.

野矢茂樹、1999、『哲学・航海日誌』春秋社.

Noonan, Harold ed., 1993, Personal Identity, Dartmouth.

Parfit, Derek, 1971a, "Personal Identity", The Philosophical Review, 80. Reprinted in Perry (1975a).

1971b, "On 'The Importance of Self-Identity"', The Journal of Philosophy, 68. Reprinted in Noonan (1993).

1976, "Lewis, Perry and What Matters", in Rorty (1976a).

1984, Reasons and Persons, Oxford University Press = 1998 森村進訳『理由と人格』勁草書房.

1986, "Comments", Ethics, 96. Reprinted in Noonan (1993).

1991, "Divided Minds and the Nature of Persons", in D. Kolak and R. Martin (eds.), Self and Identity,

New York: Machmillan.

1995, "The Unimportance of Identity", in Henry Harris ed., Identity, Oxford University Press.

Perry, John ed., 1975a, Personal Identity, University of California Press.

1975b, "The Problem of Personal Identity", in Perry (1975a)

1975c, "Personal Identity, Memory, and the Problem of Circularity", in Perry (1975a)

1976, "The Unimportance of Being Identical", in Rorty (1976a).

Reid, Thomas, 1785, Essays on the Intellectual Powers of Man, selection reprinted in Perry (1975a).

Rorty, Amélie O. ed., 1976a, Identities of Persons, University of California Press

1976b, "Introduction", in Rorty (1976a).

作田啓一、1972、『価値の社会学』岩波書店.

盛山和夫、1995、『制度論の構図』創文社.

Shoemaker, Sydney and Richard Swinburne, 1984, Personal Identity, Blackwell=1986 寺中平治訳『人格の 同一性』.

Shoemaker, Sydney, 1985, "Critical Notices: Parfit 'Reasons and Persons'”, Mind, 44. Reprinted in Noonan (1993).

Wolf, Susan, 1986, "Self-Interest and Interest in Selves", Ethics, 96. Reprinted in Noonan (1993)

(東京大学大学院人文社会系研究科博士課程; 